\title{
LABORATORY EVALUATION OF ASH MATERIALS AS ACID-DISTURBED LAND AMENDMENTS
}

\author{
H.K. KARAPANAGIOTII,* \\ AS. ATALAY2
}

Received: 22/11/00

Accepted: 20/06/01

\author{
1 ICEHT-FORTH Institute of Chemical Engineering \\ and High Temperature Chemical Processes \\ Foundation for Research and Technology Hellas, Patra \\ 2 Virginia State University, Petersburg, VA, USA \\ * to whom all correspondence should be addressed: \\ ICEHT-FORTH, P.O. Box 1414, Platani, 26500 Patra, Greece \\ tel: +30 - 61 - 965218; fax: +30 - 61 - 965223 \\ email: hrissi@yahoo.com
}

\begin{abstract}
Fly ash (FA) and fluidized bed ash (FBA) solutions were evaluated as amendments for acid-disturbed lands, more specifically for treating acidic and metal contaminated soil. While titrating the ash materials with different volumes of acid, $\mathrm{pH}$ changes were monitored as a function of time and the acid volume added. The release of metals from the ash materials as a function of $\mathrm{pH}$ was also monitored. An acid mine drainage (AMD) solution was equilibrated with ash materials and clay and the metal removal from the solutions evaluated. Both FA and FBA produced solutions of high initial pH. However, FBA indicated a higher buffering capacity resulting in a steeper titration curve. The system $\mathrm{pH}$ strongly impacted metal release from the ash materials. The leaching experiment indicated a pattern whereby the basic metals $(\mathrm{Ca}$ and $\mathrm{Na}$ ) were released at higher $\mathrm{pH}$ and the acidic metals ( $\mathrm{Fe}$ and $\mathrm{Cr}$ ) at lower $\mathrm{pH}$. Limestone had almost double the buffer intensity but a lower initial $\mathrm{pH}$ than ash materials. Comparison of ash materials with two types of clay revealed that ash materials were better alternatives for treating acidic and high metal content wastes. Albeit both ash materials were able to treat AMD, their overdose could lead to trace metal accumulation with negative consequences to the environment.
\end{abstract}

KEY WORDS: fly ash, fluidized bed ash, acid mine drainage

\section{INTRODUCTION}

Fly ash (FA) is a residue left after coal has been burned; it is collected from gas stacks using specialized devices. Fly ash properties are diverse and depend on the nature of the coal and the combustion process. Alkalinity is an important FA characteristic. Some FA materials have $\mathrm{pH}$ values as low as 4 (EPA, 1986; de Groot et al., 1987), while others have $\mathrm{pH}$ as high as 12.0 (Reed et al., 1976) and 12.7 (de Groot et al., 1987; van der Sloot, 2001). The subbituminous and lignite coal ashes produce alkaline solutions upon contact with water. Minerals such as calcite, amorphous silicates, hematite, quartz, mullite, metal oxides, and free carbon tend to exist along with alkaline FA (EPA, 1986). According to the Electric Power Research Institute (EPRI, 1988), the alkalinity depends on the calcium content 
since this element is in the form of highly reactive $\mathrm{CaO}$.

Fly ash is comprised largely of soluble calcium, which is associated with the lime fraction (Theis and Wirth, 1977). The $\mathrm{pH}$ measured for several 1:1 $\left(\mathrm{H}_{2} \mathrm{O}: \mathrm{FA}\right)$ suspensions generally shifts with time (EPRI, 1993). Initially, condensation of $\mathrm{H}_{2} \mathrm{SO}_{4}$ on the surface of the ash particles may lower the system $\mathrm{pH}$. Later, a rapid rise in $\mathrm{pH}$ is observed which is caused by the neutralization of the $\mathrm{H}_{2} \mathrm{SO}_{4}$ via dissolution of alkali and alkaline earth oxides (e.g., $\mathrm{CaO}, \mathrm{MgO}, \mathrm{K}_{2} \mathrm{O}$, and $\mathrm{Na}_{2} \mathrm{O}$ ). These oxides are present in the samples in excess of the $\mathrm{H}_{2} \mathrm{SO}_{4}$ condensate. In such cases, the $\mathrm{pH}$ measurements should be conducted after a minimum of 24 hours. Other studies (EPRI, 1993; Daniels et al., 1993) have reported changes in $\mathrm{pH}$ of FA suspensions even up to 21 days. The quantity of FA added to an aqueous solution significantly impacts the $\mathrm{pH}$. For instance, decreasing the FA percentage from $1.0 \%$ to $0.03 \%$ only decreased the $\mathrm{pH}$ by 1 unit (Reed et al., 1976). It seems that addition of a small quantity of FA can result in a significant increase of solution $\mathrm{pH}$.

Fluidized bed ash (FBA) is produced during fluidized bed combustion. This process has been used recently to burn low quality coal and to remove sulfur dioxide from exhaust gases. The coal is mixed with limestone or dolomite dust during combustion. Fly ash removed via the air control equipment is mixed with the bottom ash; this blend of ash is called FBA (Canty, 1993). The amount of calcium in FBA is higher than in FA. Limited research has been conducted on FBA related to its alkalinity. FBA has been applied to agricultural and brine contaminated lands as a source of micronutrients and as a neutralizer for low pH soils (Stout et al., 1988; Stout et al., 1997; Pyle, 1996; Meo et al., 1999).

Trace metal desorption from FA decreases with increasing $\mathrm{pH}$ (Theis and Wirth, 1977). Most trace metals show minimum release at $\mathrm{pH}$ values around 9. The desorption degree of trace metals from FA is determined by the solubilization extent of their oxide forms. In contrast, $\mathrm{Zn}$ is quite soluble in the resulting solutions, but it is poorly desorbed at neutral $\mathrm{pH}$. Lead is relatively insoluble and yet it is released from FA to a greater extent than other more soluble species. Large amounts of $\mathrm{Cl}$ and $\mathrm{SO}_{4}^{2-}$ are typically released from FA, which could potentially pro- duce soluble inorganic complexes (Theis and Wirth, 1977). Trace metals bonded with the silica present on the ash surface can only be released through the action of long-term weathering. Iron oxide controls sorbed trace metals more than aluminum oxide. Manganese oxide has a greater sorptive capacity than iron oxide, but it is present in comparatively small amounts. Each trace metal is associated with a certain oxide. In order to prevent the release of trace metals, the dissolution of iron and manganese should be controlled (Theis and Wirth, 1977).

Leaching alone generally desorbs trace metal amounts from FA. To increase the effectiveness of leaching, the use of higher solvent volumes, higher temperatures, longer contact times and lower solid-to-liquid ratios are required. However, it is not probable that the above conditions will occur in natural systems (Burnet, 1987). Baba (2000) observed lower leaching when using water alone compared to acid addition. Sulfur and $\mathrm{Ca}$ are the major soluble elements in pore waters and leachate. Most of the solubility-controlling solids are $\mathrm{SO}_{4}^{2-}$ and $\mathrm{OH}^{-}$bearing compounds (Fruchter et al., 1990). Zevenbergen et al. (1999) have observed that FA after years of application to fields is converted to fertile soil.

Preliminary investigation has shown that FA is capable of neutralizing acid mine drainage (AMD) of $\mathrm{pH} 5$ and adsorbing the metals present (Atalay et al., 1992). Twenty grams FA per liter of AMD resulted in lower turbidity solutions compared to other FA:AMD ratios. Fly ash has also been used in several sorption studies involving cations; many of them reported removal of cations. The only cation that FA proved unable to adsorb efficiently was $\mathrm{Hg}$ (Gangoli et al., 1975). Moreover, sorption of metal ions on the FA surface is substantially reduced when the $\mathrm{pH}$ of the final solution is in the acid range (Gangoli et al., 1975). For lead, the percentage sorption on FA increases in the $\mathrm{pH}$ range of 3 to 5 (Mathur and Rupainwar, 1988). The removal of Cd by sorption on FA increases with increased $\mathrm{pH}$ values from 2 to 8 , and is maximum between 7 and 8 (Viraraghavan and Rao, 1991). For Zn, the maximum removal is noted at $\mathrm{pH} 7.5$ (Singh et al., 1991). Several authors (Mathur and Rupainwar, 1988; Sen and De, 1987; Panday et al., 1985) have reported $\mathrm{pH}$ values where maximum sorption on FA occurred and the oxides that were responsible 
for the sorption of certain ions. Sorption is observed to decrease for FA at very high $\mathrm{pH}$ values where the cations are involved in the formation of soluble $\mathrm{OH}^{-}$complexes (Yadava et al., 1987). Ricou et al. (1999) have used FA and lime for $\mathrm{Cu}, \mathrm{Zn}$, and $\mathrm{Pb}$ sorption, whereas Konstantinou and Albanis (2000) have observed herbicide bonding in FA-soil mixtures.

The objectives of this study are to: (a) evaluate the neutralization capacity of the ash materials, (b) study the metal release from these ash materials with $\mathrm{pH}$ shift, (c) document the metal removal from AMD samples with the addition of ash materials, and (d) compare the ash material properties with those of limestone and 2 clay materials.

Previous studies on ash properties have not utilized equilibrium conditions. In this study, efficiency of the ash material was examined in systems that had reached equilibrium. This is significant since ash materials that are used for treatment or disposal are generally accompanied by a lengthy contact time (equilibration).

\section{MATERIALS AND METHODS}

FA samples were shipped in plastic containers from the Oklahoma Gas and Electric Plant in Muskogee, OK. FBA samples were generated at the Shady Point Power Plant in Latimer, OK and were shipped in plastic containers by Brazil Creek Minerals, Inc., Fort Smith, AR. The acid mine drainage sample was collected from the abandoned mine "Red Oak" near Latimer, OK. The limestone used for comparison with fly ash was purchased from Fisher Scientific Company, Pittsburgh, PA. The bentonite clay was purchased from Central Bag Company, Kansas City, MO. The kaolinite clay was purchased from The Feldspar Corporation, Edgar, FL.

Two $\mathrm{H}_{2} \mathrm{SO}_{4}$ solutions were used as titrants, one at $\mathrm{pH}=1$ and the other at $\mathrm{pH}=4$. A series of $10 \mathrm{~g}$ samples of ash and limestone $\left(\mathrm{CaCO}_{3}\right)$ were weighed and placed separately in high-density polyethylene flasks. For the first batch of samples, different amounts of prepared acid solution, ranging from 20 to $1900 \mathrm{ml}$, were added in each flask. The flasks were tightly capped, placed on a shaker and shaken at constant speed. The $\mathrm{pH}$ was measured using an Orion $\mathrm{pH}$-meter, model 470A. For the first 3 days, $\mathrm{pH}$ was measured every day; later, the measurements were taken once every 3 days until 30 days. When the $\mathrm{pH}$ had stabilized, samples were considered equilibrated. For the second batch, $100 \mathrm{ml}$ of AMD sample was added to flasks containing $2 \mathrm{~g}$ of ash or clay materials. The AMD samples were either used at their natural $\mathrm{pH}$ strength or acidified to $\mathrm{pH}=1$. The flasks were shaken for 2 days and $\mathrm{pH}$ measurements were recorded.

In both batches, the samples were filtered with Whatman No. 2 filter paper. The solutions were digested with nitric acid using a Tecator Digestion Apparatus. Each digested sample was diluted to $100 \mathrm{ml}$ with double deionized water containing $2 \mathrm{~g} \mathrm{l}^{-1}$ lanthanum oxide. The diluted samples were either stored in high-density polyethylene bottles or analyzed immediately. Digested samples were analyzed for metals (Fe, $\mathrm{Mn}, \mathrm{Zn}, \mathrm{Mg}$, $\mathrm{Al}, \mathrm{Ca}, \mathrm{Cd}, \mathrm{Na}, \mathrm{Cr}, \mathrm{Cu}$ and $\mathrm{Ni}$ ) using a Buck Scientific Atomic Absorption Spectrophotometer VGP System Model 210. Calibration metal standards (1000 $\left.\mathrm{mg} \mathrm{l}^{-1}\right)$ were purchased from Fisher Scientific. Nitrous oxide/acetylene flame was used to measure $\mathrm{Al}$ concentrations; all other metals were analyzed with air/acetylene flame (Welz, 1985). The raw ash materials and AMD samples were digested and analyzed in a similar fashion.

\section{RESULTS AND DISCUSSION}

Table 1 presents the metal concentrations in ash materials and AMD samples. It is apparent that both ashes contain high levels of $\mathrm{Ca}$, which came from the coal combustion process. In particular, the Ca content of FBA is higher than FA because the fluidized bed combustion process operates at a lower temperature and utilizes more lime than the conventional process to strip out the sulfur from the coal. The concentration of $\mathrm{Al}, \mathrm{Fe}$, and $\mathrm{Mg}$ are so high in the ashes that their use could prove environmentally prohibitive. These results are consistent with data provided by Muskogee generation station for FA and previous analyses (Canty, 1993) for FBA. These elements can produce acidity upon oxidation and accumulate to toxic levels.

\section{Neutralization Capacity of Ash Materials}

The ash materials used in this study were considered alkaline, and titration curves were generated for their acid neutralization. Three parameters were monitored: (a) $\mathrm{pH}$, (b) amount of acid added, and (c) time. Ash buffer intensity charac- 
Table 1. $\mathrm{pH}$ and metal concentrations in ash materials and AMD sample

\begin{tabular}{|c|c|c|c|}
\hline Sample & FA & FBA & AMD \\
\hline $\mathbf{p H}$ & 11.9 & 12.4 & 4.5 \\
\hline Metals & \multicolumn{2}{|c|}{$\mathrm{mg} \mathrm{kg}^{-1}$} & $\mathrm{mg} \mathrm{l}^{-1}$ \\
\hline $\mathbf{M n}$ & 170 & 510 & 6.8 \\
\hline $\mathbf{F e}$ & 35,000 & 55,000 & 190 \\
\hline $\mathbf{Z n}$ & 180 & 250 & 3.8 \\
\hline $\mathbf{A l}$ & 52,000 & 13,000 & 8 \\
\hline $\mathbf{M g}$ & 40,000 & 18,000 & 56 \\
\hline $\mathbf{C a}$ & 210,000 & 300,000 & N/A \\
\hline $\mathbf{N a}$ & 7,500 & 1,000 & 4.1 \\
\hline $\mathbf{K}$ & 2,900 & 3,300 & N/A \\
\hline $\mathbf{C u}$ & 2,200 & 35 & N/A \\
\hline $\mathbf{C r}$ & 65 & 50 & N/A \\
\hline $\mathbf{N i}$ & 110 & 70 & N/A \\
\hline $\mathbf{P b}$ & 68 & 85 & N/A \\
\hline $\mathbf{C d}$ & $<2$ & $<2$ & N/A \\
\hline $\mathbf{A g}$ & $<30$ & $<30$ & \\
\hline
\end{tabular}

FA: Fly ash; FBA: Fluidized bed ash; AMD: Acid mine drainage; N/A: not analyzed

terizes the neutralization capacity of the ash. In this case, buffer intensity is defined as the number of moles of strong acid required to change the $\mathrm{pH}$ of the solution by $1 \mathrm{pH}$ unit (Benefield et al., 1982), and expressed by the following equation:

$$
\text { Buffer Intensity }=\mathrm{dC} \mathrm{dpH}^{-1}
$$

where, $\mathrm{dC}=$ differential quantity of strong acid added to the solution.

$\mathrm{dpH}=$ differential change in $\mathrm{pH}$ due to the addition of a strong acid.

High buffer intensity means strong resistance to $\mathrm{pH}$ change, which results in flat titration curves. The end point is another characteristic that can be determined from the titration curve. The end point is where the alkali material has been neutralized and the solution starts to become acidic.
The amount of acid needed to neutralize a given amount of ash material provides useful information for the utilization of this material in remediation of acid impacted environments. In order to calculate the end point of the titrations and the Calcium Carbonate Equivalence (CCE), the method proposed by Benefield et al. (1982) was employed. This method involves calculation of the second derivative of the $\mathrm{pH}$ versus volume added curve, as well as conversion of the volume of acid added to equivalent calcium carbonate.

Figure 1 presents the titration curves of FA, FBA, and $\mathrm{CaCO}_{3}$ with $\mathrm{H}_{2} \mathrm{SO}_{4}$ solution of $\mathrm{pH}=1$. The stepwise titration curves observed for each component is indicative of its buffering behavior. For instance, FA exhibits several steps before it reaches the end point whereas, FBA demonstrates 2 flat titration steps, and the curve is very steep at the point of neutralization. For FA and FBA, the 


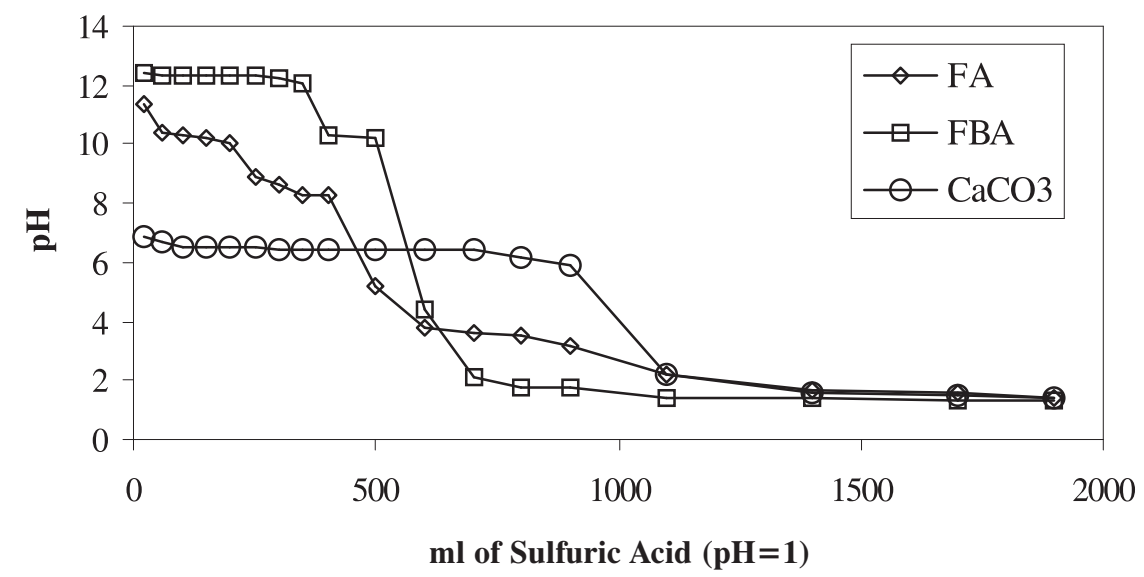

Figure 1. Titration curves for $10 \mathrm{~g}$ of ash materials and limestone against $\mathrm{H}_{2} \mathrm{SO}_{4}, \mathrm{pH}=1$ (FA: Fly ash; FBA: Fluidized bed ash).

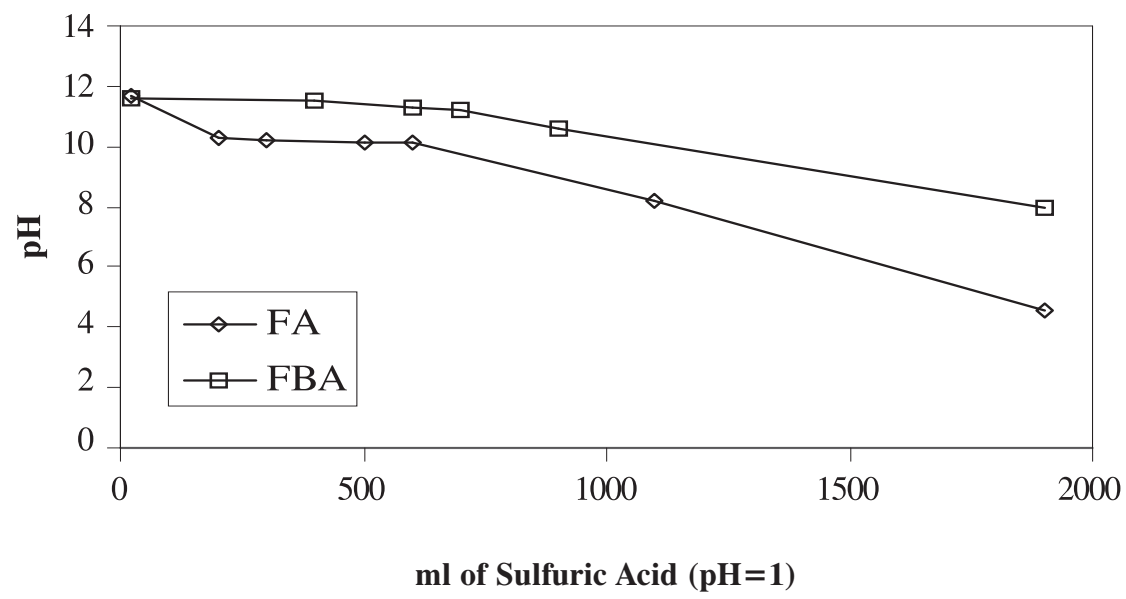

Figure 2. Titration curves for $10 \mathrm{~g}$ of ash materials and limestone against $\mathrm{H}_{2} \mathrm{SO}_{4}, \mathrm{pH}=4$ (FA: Fly ash; FBA: Fluidized bed ash).

two $\mathrm{pH}$ values with high buffer intensity were 10.5 and 8.5 and 12.5 and 9.8 , respectively. The CCE values calculated for FA and FBA were $45 \%$ and $50 \%$, respectively. The greatest buffering capacity was obtained when pure $\mathrm{CaCO}_{3}$ was used as a source of alkalinity $(\mathrm{CCE}=100 \%)$. The higher buffer intensity was observed at $\mathrm{pH}$ 6.5.

Figure 2 presents the titration curves for FA and FBA against $\mathrm{H}_{2} \mathrm{SO}_{4}$ solution of $\mathrm{pH}=4$. Dramatic changes in the titration curve patterns are apparent. Both ashes showed similar buffering potential when the acid-load was low. In this case either ash material can be used to treat the AMD. However, FBA shows greater buffering with increased addition of the diprotic acid. After the addition of almost 2 liters of $\mathrm{H}_{2} \mathrm{SO}_{4}$ of $\mathrm{pH}=4$, the $\mathrm{pH}$ in the FBA solution had only dropped from 12 to 9 indicating the strong buffering capacity of the ash. For FA and FBA, the $\mathrm{pH}$ values with higher buffer intensity were 10.5 and 11.5 , respectively. Comparing the two sulfuric acid solutions (Figures 1 and 2), it is apparent that the solution with $\mathrm{pH}=1$ causes more release of neutralizing material from the ash than the solution with $\mathrm{pH}=4$. It appears that both ashes have a certain amount of buffering capacity, which was effective in neutralizing low acidity conditions. Similar magnitude results were observed for a milder acid 


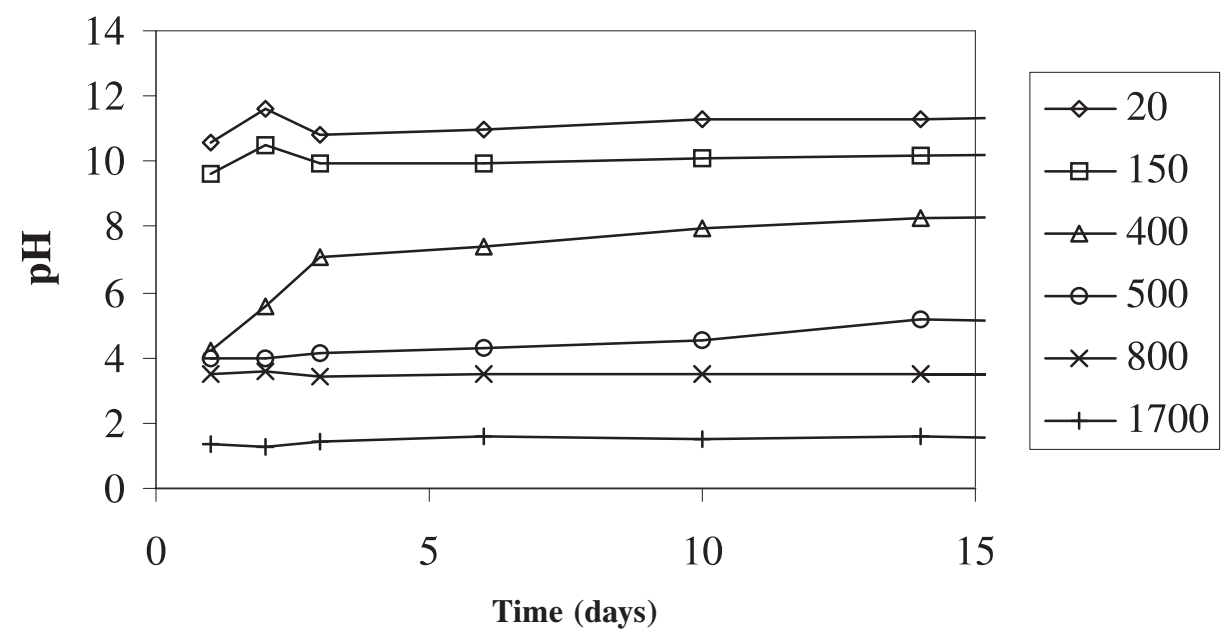

Figure 3. $\mathrm{pH}$ with time for $10 \mathrm{~g}$ of fly ash titrated with different volumes of $\mathrm{H}_{2} \mathrm{SO}_{4}(\mathrm{pH}=1)$. Numbers in legend represent $\mathrm{ml}$ of acid added.

titration $\left(0.02 \mathrm{~N} \mathrm{H}_{2} \mathrm{SO}_{4}\right)$ under anoxic conditions for these materials (Canty, 2001). For FA and FBA, $\mathrm{pH}$ values of 4.3 occurred at 175 and $450 \mathrm{ml}$ of acid $\mathrm{g}^{-1}$ of ash, respectively. Similar titrations with nitric acid (of $\mathrm{pH}=2$ ) required $800 \mathrm{ml}$ per 10 $\mathrm{g}$ of FA and $1100 \mathrm{ml}$ per $10 \mathrm{~g}$ of FBA to reach $\mathrm{pH}=7$ (Karapanagioti, 1995). In a field study 0.7 $\mathrm{g}$ of $\mathrm{FBA} \mathrm{l}^{-1}$ of acid mine drainage of $\mathrm{pH}=4.4$ were used to bring the $\mathrm{pH}=6.3$ (Meo et al., 1999). It is important to note that the volume of acid per mass of ash depends both on calcium present in the ash material (van der Sloot, 2001) and the strength of the titrating acid.

In cases where the titrant was $\mathrm{H}_{2} \mathrm{SO}_{4}$ of $\mathrm{pH}=1$ and the $\mathrm{pH}$ was raised above 8.5 , FBA showed higher buffer intensity than FA. Use of $\mathrm{CaCO}_{3}$ provided twice the buffering intensity of any of the ashes. When $\mathrm{H}_{2} \mathrm{SO}_{4}$ solution was diluted to $\mathrm{pH}=4$, FA was a better buffer at $\mathrm{pH}$ values above 10.5 .

The contribution of contact time towards $\mathrm{pH}$ stabilization (buffering) was studied in detail using sulfuric acid. Figure 3 presents the variation of $\mathrm{pH}$ over time for FA equilibration using different quantities of acid. The data points at the beginning of each titration curve reflect the inherent variability in the source of alkalinity in fly ash. The reason for this variation is not clear, but could be caused by interactions between the various cations and anions, which are released from fly ash during the initial reaction with the added acid. This is in agreement with results obtained in other studies (Theis and Wirth, 1977). After neutralization (volume of acid added $>500 \mathrm{ml}$ ), the titration curves reached their equilibrium value on the first day, as indicated by the long plateau region. When the amount of acid added increased from $500 \mathrm{ml}$ to $1700 \mathrm{ml}$, the FA was overwhelmed and its buffering capacity was exhausted. As a result, the $\mathrm{pH}$ of the solution remained below 4.0. This observation agrees with those made by other investigators (EPRI, 1993). The highest shift in $\mathrm{pH}$ observed was 4 units for the FA sample titrated against $400 \mathrm{ml}$ of sulfuric acid. Field studies using FBA with acid mine drainage showed that the solution $\mathrm{pH}$ was raised to 12.2 in 15 hours after FBA addition and then, decreased to 6.3 after 1 year (Canty and Everett, 1999; Meo et al., 1999). This is not in agreement with the current observations, but the discrepancy can be attributed to field conditions, which could lead to incomplete mixing of ash and AMD.

From the results presented previously it may be inferred that the contact time between the FA and the acid is not critical for systems with high acidity. However, for systems with low acidity, contact time and quantity of buffering material could be important. Given sufficient equilibration 


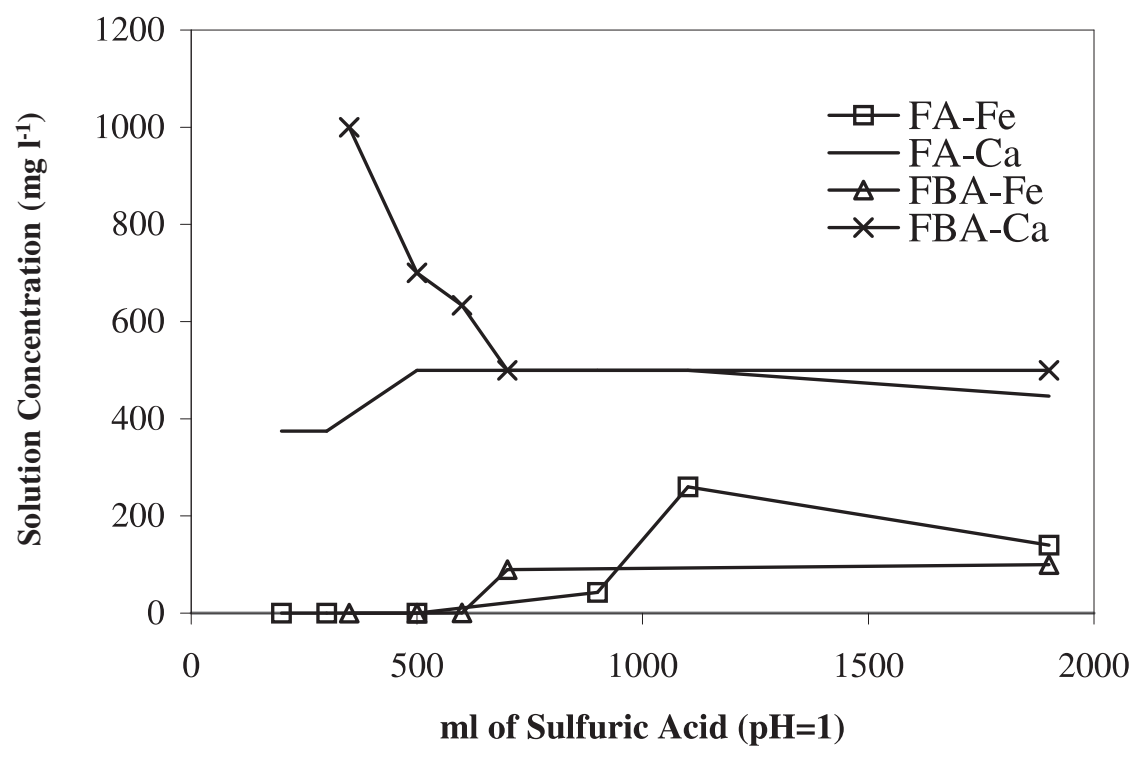

Figure 4. Iron and Ca released from ash materials after the addition of different volumes of $\mathrm{H}_{2} \mathrm{SO}_{4}, \mathrm{pH}=1$ (FA: Fly ash; FBA: Fluidized bed ash).

time, more alkalinity might be released to neutralize the acidity present in the solution.

\section{Metal Release from Ash Materials}

An experiment was conducted to evaluate the impact of gradually decreasing $\mathrm{pH}$ on the type and quantity of metals and their potential release from ash materials. It was observed that each metal had specific pattern of leaching from ash relative to $\mathrm{pH}$. As the $\mathrm{pH}$ decreases, the order of metals released observed in the current study was as follows (data not shown):

$\mathrm{Ca}-\mathrm{Na}-\mathrm{Ni}-\mathrm{Mg}-\mathrm{Pb}-\mathrm{Mn}-\mathrm{Cu}-\mathrm{Zn}-\mathrm{Al}-\mathrm{Fe}-\mathrm{Cr}$ (most released at high $\mathrm{pH}$ )

(most released at low $\mathrm{pH}$ )

$\mathrm{Ca}$ and $\mathrm{Na}$ are easily released into solution at high $\mathrm{pH}$, whereas $\mathrm{Fe}$ and $\mathrm{Cr}$ required very acidic conditions for their release. Higher concentrations of $\mathrm{Ni}, \mathrm{Cu}, \mathrm{Cr}$ and $\mathrm{Fe}$ were released from FA. The FBA released high concentrations of $\mathrm{Mg}$ and $\mathrm{Ca}$ due to higher solution $\mathrm{pH}$. Table 2 presents the maximum amount of metals released and those released at $\mathrm{pH} 7$ per $\mathrm{kg}$ of ash.

Figure 4 presents $\mathrm{Fe}$ release from FA and FBA titrated with $\mathrm{H}_{2} \mathrm{SO}_{4}$ of $\mathrm{pH}=1$. The highest amount of Fe released occurred after the addition of $1900 \mathrm{ml}$ of acid solution to $10 \mathrm{~g}$ of FA whereas the highest concentrations of $\mathrm{Fe}$ in solution were found after the addition of $1100 \mathrm{ml}$ sulfuric acid. Iron began to leach from FA after $500 \mathrm{ml}$ of acid had been added and the $\mathrm{pH}$ approached 4.0. Almost no Fe was released from the solution until the point of maximum release $(\mathrm{pH}=4)$ was reached.

Figure 4 also shows Ca release from FA and FBA using the same acidic environment as for $\mathrm{Fe}$. Calcium started to be released as soon as titration began which is in agreement with the previous observations relative to the neutralization capacity of the ash material.

The solubility of metals bonded onto ashes and other alkaline materials (Fruchter et al., 1990) is controlled by either sulfate or hydroxide compounds. Qualitatively, for metals such as $\mathrm{Ca}$ whose solubility is controlled by sulfate compounds, dissolution should not be an issue for systems where sulfuric acid is added. High concentrations of sulfate anions are introduced in the solution in the form of sulfuric acid and should lead to precipitation of the compounds. The presence of $\mathrm{Ca}$ and other metals in solution is explained by other mechanisms, such as desorption or ion exchange. The occurrence of $\mathrm{Al}$ is attributed to dissolution since its solubility is dependent on the availability of hydroxide compound. While Fe solubility is also dependent on the hydroxide availability, its concentration was 
Table 2. Concentrations of metals released from $10 \mathrm{~g}$ of ash materials while titrated against $\mathrm{H}_{2} \mathrm{SO}_{4}\left(\mathrm{pH}^{2} 1\right)$.

\begin{tabular}{|c|c|c|c|c|}
\hline \multirow{3}{*}{ Metals } & \multicolumn{2}{|c|}{$\begin{array}{l}\text { Maximum Amount* Released in } \\
\text { Solutions from the Ash Material }\end{array}$} & \multicolumn{2}{|c|}{ Amount* Released at $\mathbf{p H}=7$} \\
\hline & FA & FBA & FA & FBA \\
\hline & \multicolumn{4}{|c|}{$\left(\mathrm{mg} \mathrm{kg}\right.$ of $\left.\operatorname{ash}^{-1}\right)$} \\
\hline $\mathbf{C a}$ & $85000^{1}$ & $95000^{1}$ & 13000 & 16000 \\
\hline $\mathbf{N a}$ & $5700^{2}$ & $1000^{2}$ & 1500 & 230 \\
\hline Mg & $40000^{2}$ & $16000^{2}$ & 20000 & 3700 \\
\hline $\mathbf{P b}$ & $33^{1}$ & $57^{1}$ & 4.8 & 6.5 \\
\hline Mn & $150^{1}$ & $480^{1}$ & 90 & 0 \\
\hline $\mathrm{Cu}$ & $180^{1}$ & $35^{1}$ & 7.5 & 0 \\
\hline Zn & $180^{1}$ & $25^{1}$ & 14 & 0 \\
\hline Al & $70000^{1}$ & $5000^{1}$ & 0 & 0 \\
\hline $\mathbf{F e}$ & $28000^{1}$ & $20000^{1}$ & 0 & 18 \\
\hline $\mathrm{Cr}$ & $19^{1}$ & $19^{1}$ & 0 & 0 \\
\hline
\end{tabular}

FA: Fly ash; FBA: Fluidized bed ash

${ }^{1}$ at $\mathrm{pH}$ region $1-2$

2at $\mathrm{pH}$ region 3-4

* Note these values are amounts released from fly ash and not concentrations in solution. They are directly comparable with values in Table 1 .

above that expected when dissolution was the only mechanism of action. From these observations, it appears that desorption is the predominant mechanism for the release of most metals from the ash materials.

\section{Metal Removal from AMD Using Ash Materials and Clay}

The treatment of ash with the AMD sample produced predictable results. Table 3 presents the percent removal of metals from AMD. In Case I an AMD sample which was further acidified to meet the worst case scenario (i.e., $\mathrm{pH}=1$ ) was used whereas the AMD sample used in Case II was used as obtained from the field.

Both ash samples were able to remove effectively metals present in both acidified and natural AMD samples. Iron and Mn were totally removed from both solutions, whereas $\mathrm{Zn}$ was partially removed.
The release of alkaline earth metals $(\mathrm{Ca}$ and $\mathrm{Mg})$ from ash was also measured. Interestingly, $\mathrm{Mg}$ was not released from fly ash using the natural AMD sample, but it was released in high amounts when the acidified AMD was used (Table 3 ). In both situations, FBA showed the same $\mathrm{pH}$ and metal removal capacity. However, when the $\mathrm{pH}$ of the AMD was in the acid range $(\mathrm{pH}<4)$, the $\mathrm{Ca}$ released was low. The release of $\mathrm{Al}$ in Case II was not consistent with the results obtained in the previous section. Since the $\mathrm{pH}$ value for FBA was the same in both cases, a higher release of $\mathrm{Al}$ in Case II was thought to be due to human error (such as improper data logging, etc.).

In order to compare the ash sorption characteristics to materials of similar sorptive behavior, two clays (kaolinite and sodium (Na)-bentonite) were evaluated. Kaolinite was selected for having low specific surface area and cation exchange capaci- 
Table 3. Percent metals removed for (2g) materials titrated with $100 \mathrm{ml}$ of AMD. Percent values correspond to the initial AMD solution metal concentrations presented at the $2^{\text {nd }}$ line of each Case.

Case I: Acidified AMD, $\mathrm{pH}=\mathbf{1}$;

Fe: $190 \mathrm{mg} \mathrm{l}^{-1}$; Mn: $7 \mathrm{mg} \mathrm{l}^{-1}$; Zn: $4.2 \mathrm{mg} \mathrm{l}^{-1}$; Ca: $70 \mathrm{mg} \mathrm{l}^{-1}$; Mg: $57 \mathrm{mg} \mathrm{l}^{-1}$; $\mathrm{Al}: 8 \mathrm{mg} \mathrm{l}^{-1}$

\begin{tabular}{|c|c|c|c|c|c|c|c|}
\hline Material & Final pH & Fe & Mn & Zn & Ca & Mg & Al \\
\hline FA & 5.7 & $96 \%$ & $71 \%$ & $9.5 \%$ & $-1600 \%$ & $-130 \%$ & $63 \%$ \\
\hline FBA & 12.2 & $100 \%$ & $99 \%$ & $55 \%$ & $-3100 \%$ & $100 \%$ & $0 \%$ \\
\hline Kao & 1.3 & $-8.4 \%$ & $14 \%$ & $24 \%$ & $-230 \%$ & $2.6 \%$ & $75 \%$ \\
\hline NaB & 2.9 & $37 \%$ & $-95 \%$ & $26 \%$ & $-1000 \%$ & $-35 \%$ & $-160 \%$ \\
\hline
\end{tabular}

Case II: Natural AMD, $\mathrm{pH}=4.5$;

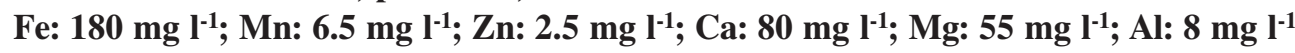

\begin{tabular}{|c|c|c|c|c|c|c|c|}
\hline Material & Final pH & Fe & Mn & Zn & Ca & Mg & Al \\
\hline FA & 11.1 & $100 \%$ & $100 \%$ & $52 \%$ & $-440 \%$ & $100 \%$ & $-400 \%$ \\
\hline FBA & 12.3 & $100 \%$ & $99 \%$ & $40 \%$ & $-2000 \%$ & $100 \%$ & $-100 \%$ \\
\hline Kao & 2.4 & $82 \%$ & $5.5 \%$ & $-40 \%$ & $-200 \%$ & $5.5 \%$ & $0 \%$ \\
\hline NaB & 6.4 & $70 \%$ & $74 \%$ & $-220 \%$ & $-210 \%$ & $64 \%$ & $-62 \%$ \\
\hline
\end{tabular}

AMD: Acid mine drainage

FA: Fly ash

FBA: Fluidized bed ash

Kao: Kaolinite

NaB: Sodium-Bentonite

Negative values indicate release of metals compared to initial concentrations.

ty (Brady, 1974). Na-bentonite is considered a high cation exchange capacity material because the sodium ion present on the active sites is easily displaced by other cations of higher valency and its high specific surface area (Lewis, 1993).

When kaolinite was titrated with the acidified AMD $(\mathrm{pH}=1), \mathrm{Mn}, \mathrm{Zn}, \mathrm{Mg}$ and $\mathrm{Al}$ were adsorbed (see Table 3). However, when it was treated with the natural AMD sample, mostly Fe (82\%) and some $\mathrm{Mn}(5.5 \%)$ and $\mathrm{Mg}(5.5 \%)$ were adsorbed. During titration with the acidified AMD sample, some Fe (37\%) and $\mathrm{Zn}(26 \%)$ were adsorbed by Na-bentonite (see Table 3). However, when the titration was performed using natural AMD, some Fe (70\%), Mn (74\%), and
$\mathrm{Mg}(64 \%)$ were adsorbed by Na-bentonite. The Na-bentonite solution resulted in a higher $\mathrm{pH}$ $(\mathrm{pH}=6.4)$ when used with natural AMD (Case II) than did the FA solution $(\mathrm{pH}=5.7)$ using acidified AMD (Case I). However, the percent metal sorption of $\mathrm{Fe}, \mathrm{Zn}$ and $\mathrm{Al}$ for $\mathrm{Na}$-bentonite was lower as compared with FA (for data see Table 3). In general, both clay materials demonstrated lower sorption behavior than the ash materials.

\section{CONCLUSIONS}

The ash products used in this study proved to be excellent buffering materials and could have great potential in improving the quality of acidic water. FBA showed a stronger buffering capacity than 
FA by releasing large quantities of alkaline material to the acidic medium. Consequently FBA could neutralize larger volume of AMD than FA when equal amounts of the ash materials are added. Calcium and $\mathrm{Na}$ were the metals most released at high $\mathrm{pH}$, whereas $\mathrm{Al}, \mathrm{Fe}$ and $\mathrm{Cr}$ were released at lower $\mathrm{pH}$. Ash materials were able to neutralize AMD samples and remove metals from solution. Either FA or FBA could be recommended for AMD treatment.

\section{ACKNOWLEDGMENTS}

The Oklahoma Conservation Commission and the United States Environmental Protection Agency supported this study through Section 319 program. The authors would like to thank Geoff Canty and Hans van der Sloot for helpful discussions during the revision of this paper. The lead author would also like to acknowledge the support of Vasilis Burganos (ICEHT/FORTH) for allowing me to continue pursuit of this publication.

\section{REFERENCES}

Atalay, A., Chaluvadi, S., Laguros, J.G. and Black, J.J. (1992), Treatment of acid mine drainage water using fly ash and water softening sludge, In: Material Research Society Symposium Proceedings, 245, 89-94.

Baba, A. (2000), Leaching characteristics of wastes from Kemerköy (Muğla - Turkey) power plant, Global NEST: The International Journal, 2, 51-57.

Benefield, D.L., Judkins, J.F. and Weand, B.L. (1982), Process chemistry for water and wastewater treatment, Prentice-Hall, Inc., NJ, USA.

Brady, N.C. (1974), The nature and properties of soils, McMillan, NY, USA.

Burnet, G. (1987), Aspects of disposal, environmental impact and resource recovery from coal combustion solid wastes, In: Papers from “Ash-A Valuable Resource” Conference, Volume 1, Council for Scientific \& Industrial Research, Republic of South Africa.

Canty, G.A. (1993), The feasibility of utilizing fluidized bed ash as a liner constituent in solid waste landfills, M.S. thesis, The University of Oklahoma, Norman, OK, USA.

Canty, G.A. and Everett, J.W. (1999), An in-situ remediation method for abandoned underground coal mines using coal combustion products, In: Proceedings: $13^{\text {th }}$ International Symposium on the use of coal combustion products, EPRI, Palo Alto, CA, USA.

Canty, G.A (2001), Oklahoma Conservation Commission, personal communication.

Daniels, W.L., Stewart, B. and Jackson, M. (1993), Utilization of fly ash to prevent acid mine drainage from coal refuse, EPRI TR-101774, In: Proceedings of the Tenth International Ash Use Symposium, Volume 1: High Volume Uses/ Concrete Applications, Washington, DC, USA.

de Groot, G.J., van der Sloot, H.A. and Wijkstra, J. (1987), Leaching characteristics of hazardous elements from coal fly ash as a function of the acidity of the contact solution and the liquid/solid ratio. In: Environmental aspects of stabilization and solidification of hazardous and radioactive wastes, ASTM STP 1033, P.L. Cttı and T.M. Gilliam, (Eds.), American Society for Testing and Materials, Philadelphia, 1989, 170-183.

Electric Power Research Institute (EPRI) (1988), Coal ash and the environment: characteristics of fly ash, EPRI RP2485-8, Technical Brief, Electric Power Research Institute, Palo Alto, CA, USA.

Electric Power Research Institute (EPRI) (1993), Detailed physical, chemical, and mineralogical analyses of selected coal and oil combustion ashes, EPRI TR-101785, Final Report, Electric Power Research Institute, Palo Alto, CA, USA.

Environmental Protection Agency (EPA) (1986), Stabilization/solidification of hazardous waste, EPA/600/D86/028, Industrial Environmental Research Lab, Cincinnati, OH, USA.

Fruchter, J.S., Dhanpat, R. and Zachara, J.M. (1990), Identification of solubility-controlling solid phase in a large fly ash lysimeter, Environmental Science and Technology, 24, 1173-1179.

Gangoli, N., Markey, D.C. and Thodos, G. (1975), Removal of heavy metal ions from aqueous solutions with fly ash, In: Proceedings of the $2^{\text {nd }}$ National Conference on Complete Water Reuse, Chicago, IL, USA.

Karapanagioti, H.K. (1995), Neutralization and sorptive properties of fly ash, M.S. thesis, The University of Oklahoma, Norman, OK, USA.

Konstantinou, I.K. and Albanis, T.A. (2000), Adsorption-desorption studies of selected herbicides in soil-fly ash mixtures, Journal of Agricultural and Food Chemistry, 48, 4780-4790.

Lewis, R.J.Sr (1993), Hawley's Condensed Chemical Dictionary, Van Nostrand Reinhold Company, NY, USA. 
Mathur, A. and Rupainwar, D.C. (1088), Removal of lead from polluted waters by adsorption on fly ash, Asian Environment, 10, 19-25.

Meo, M., Laguros, J.G. and Robertson, J.M. (1999), Current research on the greening of technology and public policy in Oklahoma, In: Proceedings of the $6^{\text {th }}$ International Conference on Science and Technology, Pythagorio, Samos, Greece.

Panday, K.K., Prasad, G. and Singh, V.N. (1985), Copper (II) removal from aqueous solutions by fly ash, Water Research, 19, 869-873.

Pyle, T.A. (1996), Investigation of a brine disturbed land: A proposed reclamation study, M.S. thesis, The University of Oklahoma, Norman, OK, USA.

Reed, D.G., Mitchell, D.T. and Parker, D.G. (1976), Water quality effects of aqueous fly ash disposal, In: Proceedings of the $31^{\text {st }}$ Industrial Waste Conference, Purdue University, Lafayette, ID, USA.

Ricou, P., Lécuyer, I. and Le Cloirec, P. (1999), Removal of $\mathrm{Cu}^{2+}, \mathrm{Zn}^{2+}$ and $\mathrm{Pb}^{2+}$ by adsorption onto fly ash and fly ash/lime mixing, Water Science and Technology, 39, 239-247, 1999.

Sen, A.K. and De, A.K. (1987), Adsorption of Mercury (II) by coal fly ash, Water Research, 21, 885-888.

Singh, A.K., Singh, D.P. and Singh, V.N. (1991), Fly ash for the treatment of $\mathrm{Zn}$ (II) rich effluents, The Environmentalist, 11, 217-224.

van der Sloot, H.A. (2001), Netherlands Energy Research Foundation, personal communication.

Stout, W.L., Daily, M.R., Nickeson, T.L., Svendsen, R.L. and Thompson, G.P. (1997), Agricultural uses of alkaline fluidized bed combustion ash: case studies, Fuel, 76, 767-769.

Stout, W.L., Hern, J.L., Korcak, R.F. and Carlson, C.W. (1988), Manual for applying fluidized bed combustion residue to agricultural lands, ARS-74, U.S. Department of Agriculture, Agricultural Research Service.

Theis, T.L. and Wirth, J.L. (1977), Sorptive behavior of trace metals on fly ash in aqueous systems, Environmental Science and Technology, 11, 1096-1100.

Viraraghavan, T. and Rao, G. (1991), Adsorption of cadmium and chromium from wastewater by fly ash, Journal of Environmental Science and Health, A26, 721-753.

Welz, B. (1985), Atomic absorption spectrometry, VCH Verlagsgesellschaft mbH, Germany.

Yadava, K.P., Tyagi, B.S., Panday, K.K. and Singh, V.N. (1987), Fly ash for the treatment of cadmium (II) effluents, Environmental Technology Letters, 8, 225-234.

Zevenberger, C., Bradley, J.P., van Reeuwijk, P.L., Shyam, A.K., Hjelmar, O. and Comans, R.N.J. (1999), Clay formulation and metal fixation during weathering of coal fly ash, Environmental Science and Technology, 33, 3405-3409. 